Sergii I. Azarov ${ }^{1}$, D. S., Senior Research Associate

ORCID ID 0000-0002-9951-8867 e-mail: azarov@kinr.kiev.ua

Oleksii S. Zadunaj ${ }^{2}$, Head of the Center, Postgraduate

ORCID ID 0000-0001-8589-1604 e-mail: a.zadunaj@ gmail.com

${ }^{1}$ Institute for Nuclear Research of NASU, Kyiv, Ukraine

${ }^{2}$ State Research Institute of Special Communications and Information Protection, Kyiv, Ukraine

\title{
BIOSPHERIC PROCESSES FORECASTING BY THE MEANS OF SYNERGETICS
}

\begin{abstract}
Among the most pressing problems of modernity stands out the problem of determining the causes and limits of sustainability of complex ecosystems, consisting of a huge number of components. Such systems include organisms and the biosphere with its ecosystems. Under the conditions of a global ecological crisis, the survival of humanity depends on our ability to understand and predict the behavior of ecosystems and the biosphere itself.

Such forecast is a specific kind of perception, which, first, studies not what is happening, but what will be happening. The main purpose of the forecast is assessment of predicted environmental reaction to the direct or indirect human influence, as well as addressing the challenges of the future sustainable use of natural resources. We have developed methodical approaches to the biospheric processes evaluation with the help of synergestic approach are developed.
\end{abstract}

Keywords: synergetics; biosphere; forecast; modeling; chaos; population

\section{Introduction}

Nowadays, most of environmentalists understand that the biosphere is the area of human life and the source of all the benefits that are necessary for vital and operational activities. The biosphere is the only populated area of the Earth crust [1]. Life representing all the organisms is concentrated only in this thin external layer of our planet.

Human is a part of nature and its creation, but only using natural resources it can create something, and can live only in those natural conditions (temperature, pressure, humidity, atmospheric composition, etc.) to which it is genetically adapted. The biosphere is an area of the Earth occupied by biotransformers that are

(c) S.I. Azarov, O.S. Zadunaj, 2018 
represented by territorial ecosystems implement and are biogeocoenoses, which are evolving with time. Realizing the special place of humankind in the biosphere, mathematicians, physicists and environmentalists, in particular, for a long time have been attempting to forecast the type of the biosphere evolution.

Such forecast is a specific kind of perception, which, first, studies not what is happening, but what will be happening. Forecasting is a set of actions that allow making judgments about the changes in natural systems and are determined by natural processes and the impact of humanity on them in the future. The significance of the environmental forecast, especially in the area of natural resources use, cannot be overestimated. The main purpose of the forecast is assessment of predicted environmental reaction to the direct or indirect human influence, as well as addressing the challenges of the future sustainable use of natural resources.

\section{Purpose of Research}

The main goal of the research is the analysis of possible reaction of biosphere to direct or indirect human influence, as well as addressing the challenges of the future sustainable use of natural resources based on environment expected states.

\section{Research result}

In the latter half of the 20th century, as a result of computers use, the modeling moved to a qualitatively new stage in its development. The possibility of joint analysis of equation systems increased significantly with a large number of parameters, etc. However, the success of mathematical modeling depends not only on the perfection of the mathematical apparatus and the computational capabilities used, but also on how scientifically grounded the initial conditions are. The process of cognition is always associated with abstraction and perfection. However, the phenomenon model is perfect only by definition, and corresponds to reality only in some way. Models, of course, can be refined almost endlessly with recognition of more and more correct bases of their construction. At the same time, there must be a reasonable limit for such refinement connected to some rationality or constructiveness. As a rule, the model, takes into account significant effects and neglect the secondary ones. Yet, the excessive simplification of the model can wipe away all the results. However, even the most accurate models and formulas do not always lead to more accurate results and conclusions. It should be emphasized there is an interesting situation appeared in in biosphere dynamics modeling: there is increasing number of different models obtained using a variety of mathematical approaches, and the choice of mathematical apparatus is largely determined by the researcher's tastes [2]. The main difficulty in developing environmental models is the lack of sufficient number of measurements as well as knowledge about the mechanisms of environmental processes and their changes under the influence of anthropogenic impacts. Therefore, considering specific conditions, it is necessary to determine which processes in the biosphere are decisive and to the greatest extent affected by the impacts, and to model them accordingly. Thus, when constructing each model, it is necessary to set the goal of modeling, because it turns out that it is impossible to write one universal model for dealing with environmental challenges. Therefore, there is a need to create a system of models of different complexity degree.

With such a system of models, one can choose the most suitable model when solving a new challenge. Otherwise, such a model needs to be developed and this 
will be another one in the specified system of models. Biosphere processes modeling is the process of creation of a system of models that is being improved and developed. As a rule, in environmental models, each model allows you to address challenges that are impossible (or difficult) to solve with the help of other models. From the above, epy systems of biosphere processes models, developed by different authors or groups of authors are different. Different model systems by different authors very in concepts and hypotheses on which that models are based, as well as mathematical expressions taken in the functional blocks for the description of dependencies, although in different models one can distinguish the same blocks and mathematical expressions.

However, at the same time, these descriptions reliably introduce certain real processes with the accuracy that is acceptable to its authors. A reliable criterion for the fairness of a model is the correspondence between the experiment and the possibility to build assumptions on its basis. It is also important to keep in mind that as a result of the proximity of models to reality, it is always necessary to make an assessment of the reasonable accuracy depending on the required one. Thus, although there is no limit to the process of models refinement, it is always necessary to reasonably restrict the desire to know the biosphere more deeply. Identification and verification are commonly used to validate the accuracy of models.

Still, there are models that cannot be verified. They are usually needed for quantitative measurement of the variables dynamics and, in fact, is an extrapolation of measurement data made in the present to the future. The last-named, for example, include models designed to assess the climatic and environmental consequences of large-scale nuclear disasters. In modern practice, mathematical modeling there is a type of models called "mixed". In such models, some of the parameters are refined with the help of experimentation, subjected to identification and verification procedures, and the rest are used to predict the state of the modeled system in the future. The example of mixed models can be many climatic models, for example, the general circulation of the atmosphere and the ocean. Only a part of variables included in such models (atmospheric temperature in areas and average temperature of the atmosphere, etc.) can be reliably identified. Modern models have dozens and hundreds of variables and cannot be investigated by classical analytical methods. Usually, these problems are solved on the basis of reasonable experience of the assumption that new traces lie near those, that were previously calculated. In addition, first, the stability of the simplified version of the model is checked, and secondly, studies of the solutions stability of the complete model is quantitatively conducted in several variants. However, due to the low speed of many evolutionary processes in the biosphere (especially such of the "geological" nature), it sometimes takes more than a decade before it is possible to see that, despite the proximity between the data on predicted and real behavior of the system for a certain time, the source references of the model were correct, and, starting at some point, the forecasts begin to fundamentally diverge from the real situation. As a rule, the number of errors in usual dynamic systems increases in proportion with time (that is, linearly) and significantly depends on the number of interactions involved: the more complex the system is, the faster the accumulation of errors in predictions in time appears. Moreover, it turns out that if the number of observed interactions exceeds a certain limit, the system soon begins to behave as a chaotic, despite the strict determinism of outgoing data. Precisely this situation, unfortunately, is implemented for most models of biosphere processes. Therefore, the probability of error in predictions of such models is usually quite 
noticeable. However, in the absence of errors, there may appear a complexity of prediction that, at first glance, contradicts the classical ideas of the dynamics.

As an illustration of the above, we present only one example that is well-known and repeatedly described in literature sources for logistic equation solutions analysis as one of the simplest mathematical point of view to the variants of the recording which can be represented as:

$$
x_{n}+1=p x_{n}\left(1-x_{n}\right)
$$

By using equation (1), for example, we can analyze the population size $N(t)$, for convenience assuming that a certain reproduction season occurs for such species once a year, and each year with the number $(n+1)$ the population of $N_{n}+1$ is completely is determined by its size $N_{n}$ in the previous year n, which is, $N_{n}+1=p N_{n}$, and the number of dead individuals is equal to $b N_{n}{ }^{2}$, meaning the proportional to the size of the whole population. The value of $x_{n}$ in this case may represent some conventional restricted population size, so that $x_{n}$ and $p$ are a function of the values $b, p$, and $N$. The logistic equation is a fully determined by the algorithm for determining the population size for each subsequent year, based on the knowledge of the population size for now. These calculations are easy to handle even without a computer. However, the results of such calculations are far from the simple in contrary to as they seem at a first glance. Without going into the details of the numerical solution of this equation, described in many textbooks, we will analyze only the obtained solutions. For small values of the parameter, completely deterministic results are obtained.

So, if $p$ is less than 1 , then regardless of the initial value score $x_{0}$, the number of the population is steadily decreasing and tends to zero (Fig. 1, a).
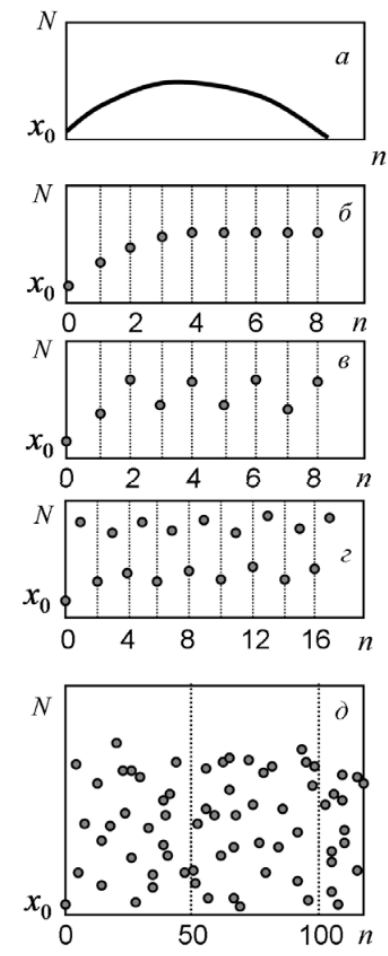

Fig. 1 - Possible changes in the population according to the logistic equation:

1. (Fig. 1, a) $-(p<1)$, the sequence of $N$ numbers is close to 0 at any initial value of $x_{0}$. This corresponds to a population that cannot avoid extinction.

2. (Fig. $1, \sigma)-(1<p<3)$, constant growth to a steady equilibrium level.

3. (Fig 1, в $)-(3<p<1+\sqrt{6})$, the number of the population rises from the initially low value, and then goes with two-year fluctuations.

4. (Fig. $1, \Gamma)-(1+\sqrt{6}<p<3,6)$, four-year cycle.

5. (Fig. 1, д) $-(p>4)$, the population starts to change chaotically, and in general its state for next year becomes unpredictable. 
From a biological point of view, this means, for example, that the resources of the habitat are too insufficient and the population is dying out. For $p$, which lies between 1 and 3 , the value of $x_{n}$ varies until it reaches the equilibrium value $x_{c o n}=(1-1 / p)$. A separate case can be seen on (Fig. 1, б). However, with values of $p$ more than 3 (extinction is not active, habitat resources are sufficient), a small initial population is steadily increasing at the beginning and then begins to fluctuate but in a very specific way. If $p$ lies between 3 and $(1+\sqrt{6})$, a deterministic sequence of $x$ values appears fluctuating with a frequency of about 2 years between two relatively constant values of $x_{p}$ and $x_{b}$ (Fig. 1, B). For $p$ slightly more than $1+\sqrt{6}=3,4495 \ldots$ the fluctuations occur between four constant values, with intervals of four years (Fig. 1, г). At even higher values of $p$, the period doubles over and over again, faster and faster (Fig. 2), until $p$ reaches the critical mark $p_{c r} \approx 3,6$, above which the population size will not begin to change in a complicated and extremely spontaneous manner.

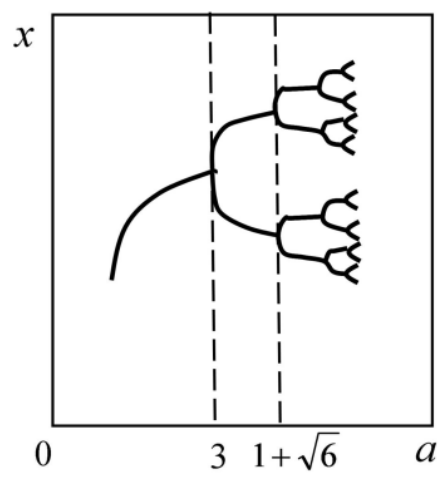

Fig. 2 - «Way» to chaos through the sequence of bifurcations

The value of $x$ (and hence of $N$ ) varies according to strict sequence between a number of admissible values ranges but the exact positions influenced by the variable within each range look completely random. With a further increase of $p$, the ranges merge with each other in pairs, and the area of values, where $N$ changes randomly increases until continuum is formed, which covers all values of $x$ in case $p>4$. The population varies in a completely random way (Fig. 1, д).

Currently, it is mathematically proved that in this case we are dealing with a completely chaotic process that resembles to the work of the well-known computer function RND (randomize) that generates a sequence of random numbers.

Such an unpredictable type of population behavior for values $p>4$ is known as deterministic chaos. Such a type of chaos arises in many dynamic systems, and the transition principles to chaos does not depend on the precision components of the systems being studied.

An important result of this approach is that it is impossible to clearly predict the behavior of the system in the future as well as to restore the "exact" history of evolution when dealing with nonlinear observing systems over the "reality". One can speak relatively straightforward only about the general tendencies of evolution. The biosphere itself, apparently, uses deterministic chaos in the process of producing, for example, new types of biodiversity or turning the backward matter into life, or trying to find out how an immune system of a body recognizes pathogenic microorganisms. 
Theoretically, the biosphere can be both deterministic and spontaneous. In practice, however, determinism requires openness, which is a necessary but not sufficient condition for self-organization.

Openness requires the presence in the sources system and/or channels of matter and/or energy exchange with environment. Nonlinearity, the presence of many solutions, according to which there are many ways of system development. Any system can be represented as an infinite series of harmonics with some temporary coefficient before each of them. In this context, in the case of independence of harmonics from each other, the system is linear, otherwise, when a certain connection between the harmonics is seen, the system becomes nonlinear.

The rate of process reaction during the evolution of the biosphere can have tangible differences. Slow processes based on a negative feedback, which serves as a stabilizing factor, allowing the system to return to equilibrium. Such a path of biosphere evolution is considered a dead end. It leads to the emergence of species, for which the further development practically stops. In general, the system of negative feedback provides protection of the biosphere from harmful influences. High-speed processes occur due to nonlinear positive feedback. This is a path that is carried out using bifurcations, during which there is a significant restructuring of the biosphere.

In order to ensure its life sustaining activities, the biosphere uses external energy sources such as sunlight, cosmic rays and radioactive decay energy of radioactive elements inside the Earth. Due to this, it is maintaining a relatively stable condition for a long time as well as biosphere evolution, accompanied by a change in its species diversity, etc., is carried out.

At the same time, during the biosphere evolution, reliable mechanisms for its protection from both external and internal factors were developed. One of such mechanisms that helps to stabilize the characteristics of the biosphere, as we have already pointed out, is the mechanism of counteracting causes and various factors, which is "pushing" the biosphere to change its state. In accordance with modern ideas, the course of evolution is followed by "slow" changes in the biosphere, as well as major catastrophes, leading to significant changes in it. But at the same time, the survivability of the biosphere as a system was always maintained.

In the modern real and material world, both order and chaos are observed in the biosphere at the same time. Chaos is understood as disorganized, shapeless structures or disordered forms of motion [3]. Researchers prove that there is a simultaneous merger of order and disorder, regularity and chaos present in the biosphere. There are ordered forms of motion and ordered structures that appear from the originally disordered, unregulated forms of motion without external influences. This phenomenon was called self-organization. German scientist H. Haken called the theory of self-organization the "synergy" (the theory of joint action) [4]. The interdisciplinary science of synergetics is closely connected to the biosphere theory. One of the synergy developers, the Nobel Prize winner in chemistry I. Prygozhyn, affirmed [5] that the relationships between order and disorder characterize sparse (dissipative) structures. Externally, occasional, uncertain wanderings are happening. This appears due to the fact that the world that surrounds us cannot be characterized by one truth, one criterion. Uncertainty dominates there. Therefore, in the process of evolution of two identical systems, the same conditions and causes do not lead to identical results. I.I. Prygozhyn believed [6] that in natural systems the order may be equilibrium and unbalanced. The biosphere organization is an open system of nonequilibrium order and operates in conditions of uncertainty. In open systems, random 
deviations (fluctuations) are constantly trying to unbalance the biosphere. I. Prygozhyn affirmed [7] that strict determinism in the outside world (the strict correspondence of causes and consequences, impacts and results) can be applied only in simple limiting cases. Randomness is seen not as an exception, but as a general rule. Hence, philosophical determinism in relation to natural systems becomes inaccessible, it is only a theoretical possibility. For many years, the principle of linearity was dominated in many fields of science. Most of the forecasting methods were based on it. Recently, in science, linearity began to be considered only as a result of simplification, coarsening of the models used. That means that in the process of biosphere development, the same causes can lead to similar investigations only at very limited segments of time. At other times, the biosphere develops in nonlinear way. For any nonlinear system, a bifurcation is usual characteristic, which means that every cause leads to, at least, two consequences. At the point of bifurcation (split), the path of the biosphere evolution becomes less stable and split into many new paths (Fig. 2). It is impossible to predict, from which of them the development of the biosphere will start. Even the smallest random variation (fluctuation) can change the possible path of the biosphere evolution, and the system will choose another direction. According to I. Prygozhyn [8], the history of the biosphere development is driven by events. However, they cannot be calculated in advance as it is the offspring of the various forces effect, the result of the interaction of many factors. Synergetics focuses on aspects of reality, that are most usual characteristics of the accelerated natural phenomena in its modern stage, which are disorder, instability, diversity, imbalance, nonlinear relations, in which a small signal at the input can cause a response of any force at the exit, as well as temporality, which is an increased sensitivity to the flow time. Mastering the basic provisions of synergetic changes, the perception of natural phenomena. The biosphere seen by researchers not as a set of rigid, unchanging systems, subsystems, elements, but in the form of processes, vortices, turbulent phenomena, dissipative (sparse) structures. This allows to use a new approach to the process of biosphere studying.

According to I. Prygozhyn, the entire evolution of the biosphere is a chain of successive bifurcations. Modern ideas of synergetic show that catastrophic changes in the biosphere occurred when, for any reason, the evolutionary change in the biosphere state led to the emergence of a strong nonlinear counteraction to the evolution process and the emergence of the bifurcation point $[5,6]$. Bifurcation is way of counteracting powerful perturbation. When bifurcation algorithm of evolutionary process increases significantly, the risk of environmental disasters and even the destruction of biosphere's individual parts. However, the destruction of the biosphere as a whole does not occur. It is possible that in an evolutionary plan, precisely the bifurcation type changes may be associated with the improvement of biosphere protecting mechanisms from excessive danger.

It is important to note that the self-provision of "safe" biosphere development and the preservation of its survivability is determined by a number of fundamental factors. Among them can be distinguished the following: firstly, the substance in the biosphere is used mainly in the form of the circular flow. Biogeochemical cycles of elements in the biosphere evolution process became so perfect that they do not lead to harmful waste appearance. Secondly, there is a huge variety of structures in the biosphere, but there are almost no dominant species with an excessive number. In this way self-regulation provides biosphere protection against possible extremely 
dangerous situations caused by internal factors. The correlation between action and counteraction entered a new stage. Therefore, according to the laws of synergetics, if counteraction under certain conditions exceeds some critical value, a bifurcation may occur and its consequences may not only be unpredictable, but also lead to the death of the human population as a whole. It has already happened for different reasons with other populations or species of living organisms. But, at the same time, it is important to remember that the biosphere evolution is a natural process that we can hardly be able to cancel and that even the complete refusal of all anthropogenic achievements of mankind we will not be able to stop this evolution, and, consequently, the change of physico-chemical biosphere characteristics. This process will always continue (perhaps at a different rate), and even if humanity, as a population, disappears from the Earth and the human impact on the environment will cease.

\section{Conclusions}

Taking into account the above, it can be affirmed that the issues of solving problems referred to as environmental ones, in fact, are beyond the scope of ecology in its traditional formulation. It is already evident that the solution of these problems requires both additional new knowledge and a new mentality. It is necessary to look for new ways not only for solution, but also for justification of environmental issues. In general, the biosphere protection from "excessive danger" is provided by a system of negative feedback which operates within the framework of objectively existing laws of nature ( $2^{\text {nd }}$ law of thermodynamics, biogeochemical cycles, information biodiversity, etc.), so it can be affirmed that the biosphere has peculiar characteristic of internal security.

New ideas and concepts of modern nonlinear dynamics have significantly changed our perceptions of the accident in the behavior of complex systems and the biosphere in particular. The most surprising thing in the nonlinear systems behavior is that even a system characterized by classical laws of dynamics can have chaotic motion paths, despite its initial determinism. It turns out that stochastic behavior is merely the result of a simple mechanical repetition of some, often quite simple, algorithmic procedure. At the same time, strictly deterministic feature appears to be simultaneously both in random and chaotic. In nonlinear systems, the number of errors in "prediction" increases with increasing of the process rate (exponentially with time). Therefore, the unpredictability of the "exact future" is fundamental and is explained by not only our ignorance or the presence of errors in the initial conditions. It is important to understand that modeling allows forecasting the most probable and possible ways of biosphere evolution, but not necessarily are implemented or those that are going to be implemented in the future.

\section{REFERENCES}

1. Моисеев Н.Н. Человек и биосфера. Опыт системного анализа и эксперименты с моделями / Моисеев Н.Н., Александров В.В., Тарко А.М. - М.: «Наука», 1985. - 271 с. 2. Хатчисон Дж. Биосфера // Биосфера. М.: Мир, 1972. С. 5-25.

3. Хакен Г. Синергетика. Пер. с англ. / Под ред. Ю.Л. Климантовича, С.М. Осовца. М.: Мир, 1980. - 404 с.

4. Хакен Г. Синергетика : Иерархия неустойчивостей в самоорганизующихся системах и устройствах : пер. с англ. - М. :Мир, 1985. - 423 с.

5. Пригожин И. От существующего к возникающему. Пер. с англ. Под ред. Ю.Л. Климантовича. - М.: Наука, 1985. - 328 с. 
6. Пригожин И. Познание сложного. Введение / Г. Николис, И. Пригожин : пер. с англ. - 2-е изд., стер. - М. : Едиториал УРСС, 2003. - 344 с

7. Пригожин И., Стенгерс И. Порядок из хаоса (Новый диалог человека с природой) / Пригожин И., Стенгерс И. - М.: изд-во «Едиториал УРСС», 2003. - 310 с.

8. Пригожин. И. Время, хаос, квант : пер. с англ. / И. Пригожин, И. Стенгерс. - М.: Издательская группа «Прогресс», 1999. - 268 с.

\section{REFERENCES (TRANSLATED AND TRANSLITERATED)}

1. Moiseev, N. N., Aleksandrov, V. V., \& Tarko, A. M. (1985). Chelovek i biosfera. Opyt sistemnogo analiza i jeksperimenty s modeljami. Moscow: Nauka (in Russian).

2. Hutchison., J. (1972). Biosphere. Moscow: Mir (in Russian).

3. Haken, H. (1980). Synergetics (J. L. Klimantovich \& S. M. Osovec, Eds.; V. I. Emel'janov, Trans.). Moscow: Mir (in Russian).

4. Haken, H. (1985). Synergetics: The hierarchy of instabilities in self-organizing systems and devices. Moscow: Mir (in Russian).

5. Prigogine, I. (1985). From Being To Becoming (J. L. Klimantovich, Ed.). Moscow: Nauka (in Russian).

6. Prigogine, I., \& Nikolis, G. (2003). Poznanie slozhnogo. Vvedenie. Moscow: «Editorial URSS» (in Russian).

7. Prigogine, I., Stengers, I. (2003). Order out of Chaos: Man's new dialogue with nature. Moscow: «Editorial URSS» (in Russian).

8. Prigogine, I., \& Stengers, I. (1999). Time, Chaos and the Quantum. Moscow: «Progress» (in Russian).

Text of the article was accepted by Editorial Team 18.09.2018

\section{С.І. Азаров, О.С. Задунай}

\section{ПРОГНОЗУВАННЯ БІОСФЕРНИХ ПРОЦЕСІВ ЗА ДОПОМОГОЮ СИНЕРГЕТИКИ}

Анотація. Серед найбільш актуальних проблем сучасності виділяється проблема з'ясування причин і меж стійкості складних екосистем, що складаються з величезного числа компонентів. До таких систем відносяться організми і біосфера 3 ii екосистемами. В умовах планетарної екологічної кризи від нашого вміння розуміти i передбачати поведінку екосистем і самої біосфери залежить виживання людства.

Прогноз являє собою специфічний вид пізнання, де, перш за все, досліджується не те, що $\epsilon$, а те, що буде. Головною метою прогнозу є оцінка передбачуваної реакції навколишнього природного середовища на прямий або опосередкований вплив людини, а також вирішення завдань майбутнього раціонального природокористування. Нами розроблено методичні підходи до оцінки біосферних процесів за допомогою синергетичного підходу.

Ключові слова: синергетика; біосфера; прогноз; моделювання; хаос; популяція

\section{Азаров Сергій Іванович}

доктор технічних наук, старший науковий співробітник, провідний науковий співробітник Інституту ядерних досліджень НАН України

Адреса робоча: 03680 Україна, м. Київ, пр-т Науки, 47

ORCID ID 0000-0002-9951-8867 e-mail: azarov@ kinr.kiev.ua

\section{Задунай Олексій Сергійович}

здобувач наукового ступеня кандидата технічних наук, начальник центру Державного науково-дослідного інституту спеціального зв'язку та захисту інформації

Адреса робоча: 03142 Україна, м. Київ, вул. М. Залізняка, 6

ORCID ID 0000-0001-8589-1604 e-mail: a.zadunaj@ gmail.com 